\title{
LAMB GROWTH ON "LONG" AND "SHORT" GRAZED PASTURES OF RYEGRASS OR TIMOTHY/COCKSFOOT
}

\author{
K. H. C. Lewis and N. A. Cullen \\ Invermay Agricultuml Research Centre, Mosgiel
}

\section{A bstract}

Lamb growth rates were measured on "long" $(>5 \mathrm{~cm})$ and "short" $(<5 \mathrm{~cm})$ ryegrass and timothy/cocksfoot pastures sown with clovers.

Both before and after weaning in December, the growth rates of lambs were similar on "short" pastures but lower on "long" ryegrass pastures than on "long" timothy/cocksfoot pastures.

Before weaning, gains on "short" ryegrass pastures were higher than those on "long" but with timothy/cocksfoot the position was reversed. After weaning, "short" pastures of both types produced higher gains than "long" pastures.

The main factor affecting lamb growth rate appeared to be the deterioration of leniently grazed swards in late summer and autumn.

\section{INTRODUCTION}

Trials by Lewis and Cullen (1964) showed that lamb growth rates on timothy/cocksfoot and perennial ryegrass pastures were similar prior to the time of ryegrass seeding after which timothy/ cocksfoot produced better gains. At this later time clover content, rather than grass species, appeared to be the more important factor. In these trials the lamb growth rates reflected the characteristics of the pastures under conditions of abundant feed.

In the experiment now reported, ryegrass and timothy/cocksfoot pastures were compared under lenient and close grazing (simulated by additional mowing of the grazed sward). Two periods within one season were studied, pasture type and length being related to the growth rate of lambs before and after weaning in December.

\section{EXPERIMENTAL}

An area of 6 ha was divided into 8 paddocks and sown in February 1960 in four replicates with either:

(1) Ruanui ryegrass $\quad 22.4 \mathrm{~kg} / \mathrm{ha}$ Manawa ryegrass $\quad 5.6 \mathrm{~kg} / \mathrm{ha}$
(2) Kahu timothy Apanui cocksfoot

$$
\begin{aligned}
& 2.2 \mathrm{~kg} / \mathrm{ha} \\
& 2.2 \mathrm{~kg} / \mathrm{ha}
\end{aligned}
$$


each with crested dogstail 2.2, Huia white clover 3.4, and Turoa red clover $3.4 \mathrm{~kg} / \mathrm{ha}$. The seed was broadcast with $250 \mathrm{~kg} / \mathrm{ha}$ DDT-superphosphate.

Grazing treatments were:

(1) Closely grazed ("short") $<5 \mathrm{~cm}$ mean pasture height

(2) Leniently grazed ("long") $>5 \mathrm{~cm}$ mean pasture height

The desired pasture height was maintained by periodic mowing. A split plot design was used with pasture type as the main plots and grazing height randomized in the two sub-plots. The duration of the experiment was three years and grazing heights were re-randomized each year.

In the first season differences in pasture length were created and maintained by pre-grazing mowing and by differences in stocking rate. Each paddock was subdivided into two parts in the ratio of 7:5 by area, allowing equal. numbers of stock to be carried on the "long" treatment at a lower stocking rate than on the "short" treatment.

As differences in stocking rate might have introduced effects other than those associated with type and availability of pasture, in the second and third years subdivision was relocated to provide equal areas which were stocked with equal number of ewes and lambs.

Pasture height was recorded weekly throughout the grazing periods and herbage production measured by the enclosure technique (Lynch, 1947). Clover content was determined by the dissection of herbage mown in production cuts.

The experimental areas were set-stocked according to the

I ABLE 1: PERIOD, DURATION AND STOCKING RATE OF TRIALS

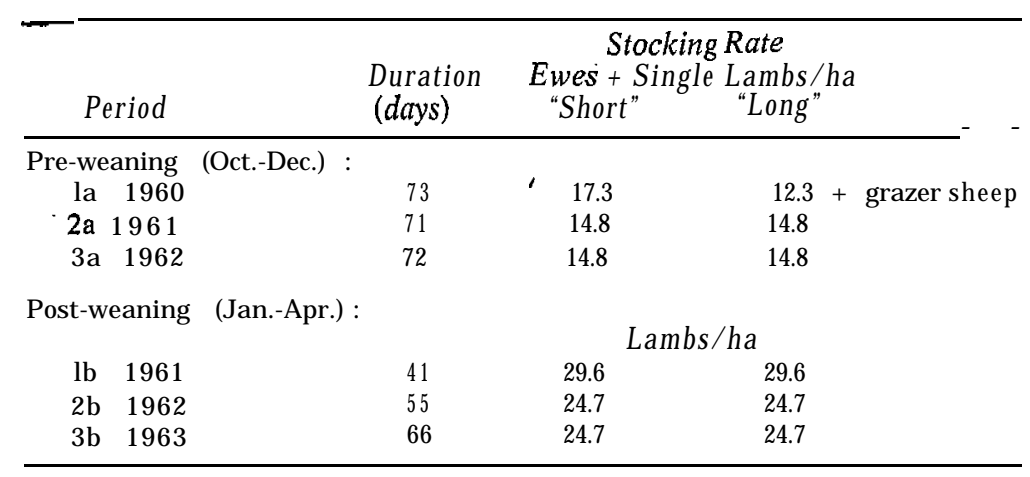




\section{LAMB GROWTH ON PASTURES}

schedule in Table 1. Lambs were weighed every two weeks. Between pre- and post-weaning periods, seedheads were trimmed and paddocks spelled prior to the introduction of other weaned lambs. These spelling periods were 21, 27 and 40 days, respectively, in each of the three seasons.

In periods $1 \mathrm{a}, \mathrm{lb}, 2 \mathrm{a}$ and $2 \mathrm{~b}$, all lambs were dosed with. an anthelmintic before or during grazing as a precaution against internal parasites. In periods $3 \mathrm{a}$ and $3 \mathrm{~b}$, half of each treatment group was dosed to evaluate possible differential effects due to parasites.

\section{RESULTS}

\section{Pasture Production and Composition}

After satisfactory establishment, all treatments were grassdominant, the clover content not exceeding $26 \%$ at any time. Timothy/cocksfoot pastures were timothy-dominant in the first year but cocksfoot increased each year to become the dominant species in the third year.

No significant differences in total dry matter productions were recorded for the two types of pasture during the experimental grazing periods. Mean dry matter production of "short" and "long" pastures of each type was $5200 \mathrm{~kg} / \mathrm{ha}$ in the pre-weaning period and $3900 \mathrm{~kg} / \mathrm{ha}$ in the post-weaning period.

TABLE 2: MEAN HEIGHT OF PASTURE (cm)

\begin{tabular}{|c|c|c|c|c|c|c|}
\hline \multirow[b]{3}{*}{ Pasture Treatment } & & & & \multicolumn{3}{|c|}{ Period } \\
\hline & \multicolumn{3}{|c|}{ Pi-eweaning } & & -weanir & \\
\hline & Ia & $2 a$ & $3 a$ & $\mathrm{lb}$ & $2 b$ & $3 b$ \\
\hline \multicolumn{7}{|l|}{ Ryegrass: } \\
\hline "Short" & 5.8 & 3.8 & 2.8 & 5.1 & 2.8 & 3.8 \\
\hline "Long" & 16.8 & 15.2 & 9.7 & 13.5 & 12.2 & 14.0 \\
\hline \multicolumn{7}{|l|}{ Timothy/cocksfoot } \\
\hline "Short" & 5.1 & 3.8 & 2.8 & 4.1 & 2.8 & 3.8 \\
\hline "Long" & 14.0 & 15.2 & 9.1 & 12.4 & 9.4 & 16.5 \\
\hline
\end{tabular}

Only limited mowing was necessary to maintain the pastures at the desired mean heights except in period la where additional grazer stock were added to "short" treatment paddocks for all but the first two weeks of grazing. Mean pasture heights for each experimental period are shown in Table 2. "Long" pastures 
tended to be selectively grazed until up to $50 \%$ of the area was below $5 \mathrm{~cm}$ in height. "Short" pastures remained dense and leafy, with a little seeding in the ryegrass only. "Long" ryegrass areas not selectively grazed seeded profusely in November, resulting in a coarse, stalky, open sward lacking in leaf.

"Long" timothy/cocksfoot pastures seeded sparingly but later developed into uneven stalky swards containing much dead matter.

TABLE 3: MEAN CLOVER CONTENT OF HERBAGE (\%)

\begin{tabular}{ccccc}
\hline Period & $R S$ & $R L$ & $T S$ & $T L$ \\
\hline la & 2.5 & 2.1 & 8.4 & 10.1 \\
2a & 6.9 & 3.2 & 7.6 & 3.7 \\
3a & 7.0 & 5.9 & 7.7 & 3.9 \\
1b & .6 .7 & 4.7 & 18.7 & 9.9 \\
2b & 16.2 & 8.0 & 16.6 & 4.6 \\
3b & 26.4 & 9.4 & 22.7 & 7.7 \\
\hline
\end{tabular}

RS - "Short" ryegrass. RL - "Long" ryegrass. TS - "Short" timothy/ cocksfoot. TL - "Long" timothy/cocksfoot.

Clover contents (Huia + Turoa) were between 2 and $26 \%$ of the herbage produced in the experimental grazing periods, Table 3 shows that the clover content of timothy/cocksfoot pastures was generally higher than that of ryegrass pastures, particularly in the first and second seasons, and consistently higher in "short" treatments than in "long". Clovers were also more abundant in post-weaning than in pre-weaning periods. Crested dqgstail was a minor component of the pastures at all times.

\section{Lamb Growth Rate}

1 Lamb liveweight gains in each year followed a similar pattern for pasture types and grazing heights. The results, which are the means of three years, were corrected for sex and analysed separately for pre-weaning and post-weaning, periods, each year being treated as a replicate. Both before and after weaning, the growth rates of lambs were similar on "short" pastures but on "long" pastures growth rates on timothy/cocksfoot were superior to those on ryegrass. Before weaning gains on "short" ryegrass were higher than those on "long" ryegrass but with timothy/cocksfoot the position was reversed. After weaning, "short" pastures of both types produced higher gains than "long" pastures (Table 4). 
TABLE 4: MEAN LIVEWEIGHT GAIN OF LAMBS (kg/head)

\begin{tabular}{|c|c|c|c|c|}
\hline \multirow{3}{*}{ Ryegrass } & \multicolumn{2}{|c|}{ Preweaning } & \multicolumn{2}{|c|}{ Post-weaning } \\
\hline & "Short" & "Long" & "Short" & "Long" \\
\hline & $16.0 \mathrm{bB}$ & $15.2 \mathrm{cB}$ & $5.7 \mathrm{aAB}$ & $2.7 \mathrm{cC}$ \\
\hline $\begin{array}{l}\text { Timothy/cocksfoot } \\
\text { CV } \%\end{array}$ & $15.7 \mathrm{bcB}$ & $17.0 \mathrm{aA}$ & $6.1 \mathrm{aA}$ & $4.1 \mathrm{bBC}$ \\
\hline
\end{tabular}

Duncan's multiple range test: Means without a common letter differ significantly (lower case, $\mathrm{P}<0.05$; upper case, $\mathrm{P}<0.01$ ).

A significant interaction $(P<0.01)$ in the pre-weaning period between pasture type and height indicated that though "long" ryegrass pastures were inferior to "short", "long" timothy/ cocksfoot pastures were superior to "short" timothy/cocksfoot pastures. This effect was not apparent in the post-weaning period where both pasture types were similar but "short" pastures produced higher weight gains than "long" pastures.

\section{PARASITISM}

In period $3 a$, growth rates were not affected by anthelmintic dosing but in period $3 \mathrm{~b}$ dosed lambs made significantly $(P<0.01)$ higher gains. There was no interaction in either period between dosing and pasture type or length. Parasitism did not differentially affect treatments and was therefore not a factor in the experiment.

\section{DISCUSSION}

The inferior gains on "long" ryegrass pastures in the preweaning period appeared. to be closely related to the onset of ryegrass seeding, as lamb growth rates were comparable on both pasture types until mid-November. Growth rates then declined under lenient grazing, where seeding of ryegrass was profuse. Close grazing and mowing of ryegrass pastures at this time not only reduced seeding but was associated with higher gains in lambs.

The significant interaction for liveweight gain in the preweaning period was largely associated with lamb growth on "long" timothy-cocksfoot pastures which, although no higher in clover content than "short" pastures of the same type, would have offered more available feed so that lambs were able to exercise a greater selectivity in their diets. However, there was no 
consistent relationship between lamb growth rates and clover content measured in the pasture.

It is clear, however, that, where ryegrass pastures were controlled by grazing or mowing so that seeding was suppressed, they were as suitable for lamb growth as controlled timothy/ cocksfoot pastures, where clover content was comparable. The superiority of "long" timothy/cocksfoot pastures was shortlived and disappeared in the post-weaning period when "long" pastures of both types became coarse, stemmy, open and appreciably lower in clover content than their "short" counterparts. Ryegrass pastures deteriorated more in terms of lamb growth quality than timothy/cocksfoot pastures, even though their clover contents remained comparable.

Even if pastures had not been spelled between pre- and postweaning periods and grazing treatments had continued, it is very doubtful whether "long" timothy/cocksfoot pastures would have retained their earlier small margin of superiority.

The results of these trials do not justify any departure from ryegrass-based pastures for lamb production but emphasize the importance of grazing control in maintaining the capacity of the pasture to promote liveweight gain in lambs.

\section{REFERENCES} Lewis, K. H. Cullen, N. A., 1964: N.Z. Journal of A griculture, 108:
537.

Lynch, P. B., 1947: N.Z. Journal of Science and Technology, 28A: 385. 